KS. MARCIN KOŁODZIEJ

\title{
Liturgia w katechezie
}

Papież Benedykt XVI list apostolski Porta fidei ogłaszający Rok Wiary zaczął od słów: „ "Podwoje wiary» (por. Dz 14, 27) są dla nas zawsze otwarte. Wprowadzają nas one do życia w komunii z Bogiem i pozwalają na wejście do Jego Kościoła. Próg ten można przekroczyć, kiedy głoszone jest Słowo Boże, a serce pozwala się kształtować łaską, która przemienia" (nr 1). Te słowa papieża mogą być inspiracją do poszukiwania odpowiedzi na pytanie, jak uczyć uczniów religii, aby doprowadzić ich do odpowiedniego udziału w liturgii. W celu wskazania odpowiedzi na to pytanie należy najpierw uchwycić rolę katechezy i liturgii w procesie formowania uczniów do wiary dojrzałej, a następnie zastanowić się nad wzajemnymi relacjami pomiędzy katechezą a liturgią.

Komunia z Bogiem oraz głęboka obecność we wspólnocie Kościoła wynikają - według Benedykta XVI - z przyjęcia słowa Bożego oraz ze wzrastania z łaską Bożą. Dlatego, aby wypełnić zadanie, które zostało postawione katechetom, należy katechizowanych nakarmić słowem Bożym i łaską Boga. Przestrzenią głoszenia słowa Bożego i obdarzania łaską Boga jest zarówno katecheza, jak i liturgia. Oczywiście każda z nich we właściwym sobie zakresie.

Liturgia i katecheza to rzeczywistości, pomiędzy którymi zachodzą wzajemne relacje. Ze ścisłym związkiem pomiędzy katechezą a liturgią mamy do czynienia w zasadzie od początku działalności Kościoła. Kościół pierwszych wieków chrześcijaństwa potrafił umiejętnie łączyć te dwie rzeczywistości. Chrześcijanie pierwszych wieków nie uprawiali w sensie ścisłym katechezy dzieci i młodzieży. Raczej praktykowali wówczas katechezę dorosłych, która dokonywała się zasadniczo podczas Eucharystii 
albo w powiązaniu z Eucharystią. Były to zabiegi słuszne. Bo jeśli należycie uformowano dorosłych chrześcijan, wówczas oni potrafili dojrzałe postawy wiary ukształtować w stosunku do swoich dzieci w swoich rodzinach.

Zatem zanim Kościół zaczął praktykować naukę religii dzieci i młodzieży oraz wpisał ją do systemu edukacji szkolnej, najpierw - już znacznie wcześniej - wychowywał ludzi do wiary dojrzałej poprzez katechezę liturgiczną. W ramach tej katechezy nie tylko głosił słowo Boże, ale też przygotowywał wiernych do przyjęcia i odpowiedniego uczestnictwa w sakramentach świętych oraz do aktywnego życia liturgicznego ${ }^{1}$.

Katechezę liturgiczną, o której była mowa powyżej, od starożytności chrześcijańskiej określano mianem mistagogii. Jej zadaniem było udzielić wiernym takiej pomocy, aby potrafili oni przejść „od tego, co widzialne, do tego, co niewidzialne, od znaku do tego, co on oznacza, od sakramentów do misteriów" (Katechizm Kościoła katolickiego, 1075). Uprawiana już wtedy mistagogia swoją drugą młodość zaczęła ponownie przeżywać po Soborze Watykańskim II. Właśnie ten sobór wskazał na mistagogię jako na warunek konieczny do ożywienia wiary. Ks. Romano Guardini - wybitny teolog tamtego okresu - podkreślał, że mistagogia jest konieczna do prawdziwego i przeżywanego bycia człowiekiem. Oznacza to, że bez katechezy liturgicznej nie ma ani dojrzałego człowieka, ani jego dojrzałej wiary ${ }^{2}$.

\section{Katecheza}

Aby dobrze uchwycić relację pomiędzy katechezą a liturgią, należy najpierw krótko skoncentrować się na istocie katechezy. Czym ona jest? Sam termin ma swoje źródło w języku greckim. Katechein oznacza odpowiadać, pouczać ustnie, nauczać przez pytania i odpowiedzi ${ }^{3}$. Definicji katechezy jest wiele - wszystkie w zasadzie są zbliżone do siebie. Papież

${ }^{1}$ H. Wrońska, Rola liturgii w katechezie, „Roczniki Pastoralno-Katechetyczne” 57 (2010) nr 2, s. 121.

${ }^{2}$ M. Kołodziej, Zgromadzenie liturgiczne jako rzeczywistość teologiczno-kanoniczna w ministerialnym posługiwaniu Kościoła, Wrocław 2012, s. 265.

${ }^{3}$ S. Hołodok, Liturgia i katecheza, „W Służbie Miłosierdzia” 2010 nr 1. 
Jan Paweł II w adhortacji apostolskiej Catechesi tradendae daje taką odpowiedź: „Katecheza jest wychowaniem w wierze dzieci, młodzieży i dorosłych, a obejmuje przede wszystkim nauczanie doktryny chrześcijańskiej, przekazywane na ogół w sposób systematyczny i całościowy, dla wprowadzenia wierzących w pełnię życia chrześcijańskiego” (nr 18).

$\mathrm{Z}$ definicji podanej przez papieża wynika, że katecheza obejmuje dzieci, młodzież i dorosłych. Na każdym etapie życia człowieka powinien on być katechizowany. Ponadto katecheza ma trzy podstawowe funkcje: wychowanie w wierze, nauczanie doktryny chrześcijańskiej oraz wtajemniczenie chrześcijańskie. Wszystkie te trzy elementy ostatecznie prowadzą do nadrzędnego celu katechezy, jakim jest doprowadzenie katechizowanych do komunii z Jezusem Chrystusem (por. Katechizm Kościoła katolickiego, 426).

\section{Liturgia}

Kolejnym krokiem koniecznym, który należy postawić w analizowanym zagadnieniu, jest zdefiniowanie liturgii. Czym ona jest? Aby ją zdefiniować, należałoby najpierw zwrócić uwagę na dwa greckie wyrazy, które składają się na ten termin. Są to: leitos („ludowy, należący do ludu”) oraz ergon („,czyn publiczny”). A zatem liturgia jest po prostu - co stanowi jej zasadniczy rys - działaniem o charakterze publicznym, wspólnotowym. W starożytnej Grecji tym terminem określano wszelkie zgromadzenia ludzi - polityczne, czy społeczne, które miały za cel służyć innym, przynosić im korzyść 4 .

Konstytucja soborowa o liturgii świętej definiuje ją jako „wypełnianie kapłańskiej funkcji Jezusa Chrystusa. W niej przez znaki dostrzegalne wyraża się i w sposób właściwy dla poszczególnych znaków dokonuje uświęcenie człowieka, a Mistyczne Ciało Jezusa Chrystusa, to jest Głowa ze swymi członkami, sprawuje pełny kult publiczny" (konst. Sacrosanctum Concilium, 7).

${ }^{4}$ B. Nadolski, Leksykon liturgii, Poznań 2006, s. 745; M. Kołodziej, Wiara celebrowana $w$ liturgii, Wrocław 2012, s. 11. 
Z tej definicji wynika, że czynności liturgiczne nie są oderwane ani od Chrystusa, ani od Kościoła. Stanowią przedłużenie długiej i bogatej historii zbawienia zapoczątkowanej w Starym Testamencie i przedłużonej w Nowym Przymierzu. Liturgia jest odzwierciedleniem tego, co czyni Chrystus. Każdy, kto uczestniczy w Eucharystii jednoczy, utożsamia się z samym Chrystusem i Jego ofiarą. Co sprawia liturgia? Z jednej strony ludzie wyrażają swoją cześć względem Boga, z drugiej zaś dokonuje się - z mocy samego Boga - uświęcenie tych ludzi.

Skoro w opisywaniu natury liturgii mówi się zarówno o Bogu, jak i o ludziach, wynika jasno, że liturgia, która ma charakter publiczny, ma być dziełem całego Kościoła. Dlatego w ramach formowania katechizowanych do wiary dojrzałej, trzeba też zaprezentować im wizję liturgii, w której nie tylko kapłan, ale również poszczególni wierni mają do spełnienia ważną rolę.

\section{Relacja pomiędzy liturgią a katechezą}

Teologowie w literaturze przedmiotu bardzo często powtarzają sentencję: „Liturgia domaga się katechezy, a katecheza domaga się liturgii”. Dlaczego? Ks. Andrzej Hajduk, który jest autorem pracy o wzajemnych relacjach pomiędzy katechezą a liturgią, stwierdził, że bez katechezy liturgia mogłaby popaść w formalizm i magizm, natomiast katecheza bez liturgii spadłaby do poziomu indoktrynacji, lekcji abstrakcyjnej i intelektualnej ${ }^{5}$. Dlatego wskazał on na trzy wymiary relacji zachodzących pomiędzy liturgią a katechezą: liturgia jest celem katechezy, liturgia jest katechezą aktywną, liturgia jest źródłem dla katechezy ${ }^{6}$.

Po pierwsze: liturgia jest celem katechezy. Jak to rozumieć? Celem samej katechezy jest doprowadzić uczniów do komunii z Jezusem Chrystusem (por. Katechizm Kościoła katolickiego, 426). Komunia z Jezusem Chrystusem zakłada potrzebę przyjmowania Jego sakramentów, pośród których Eucharystia ma miejsce naczelne (por. Kongregacja ds. Duchowieństwa, Dyrektorium ogólne o katechizacji, 85). Dlatego też osobowym spotkaniem

\footnotetext{
${ }^{5}$ A. Hajduk, Katecheza i liturgia, Kraków 1999, s. 43.

6 Tamże, s. 17.
} 
z Chrystusem, a zarazem celem katechezy staje się liturgia, która dodatkowo ukształtuje w uczestnikach odpowiednie postawy życiowe. Bo jeśli katechizowany dostrzeże podczas uczestniczenia w katechezie miłość Chrystusa, wówczas odwzajemni tę miłość Bogu. Podobnie, gdy usłyszy nakaz realizowania przykazania miłości bliźniego, wówczas będzie je praktykował.

Po drugie: liturgia jest katechezą aktywną. Jak to rozumieć? Konstytucja soborowa o liturgii świętej przypomina, że „liturgia zawiera bogatą treść dla pouczenia wiernego ludu" (konst. Sacrosanctum Concilium, 33). Każdy, kto będzie w ciągu roku liturgicznego regularnie uczęszczał na Eucharystię i uważnie w niej uczestniczył, bardzo szybko odkryje - jeśli zostanie odpowiednio pouczony - że te treści, które stanowią program nauczania w katechezie, również może usłyszeć w liturgii. Stąd też praktyka Kościoła pierwszych wieków - o której zostało stwierdzone powyżej - związana z mistagogią, czyli katechezą liturgiczną, była niezwykle cennym elementem. Jak ją podejmować? Chociażby poprzez roztropną posługę komentatora w liturgii.

Po trzecie: liturgia jest źródłem dla katechezy. Jak to rozumieć? Katecheza ma za zadanie doprowadzić katechizowanych do wiary dojrzałej. Ta dojrzałość przejawia się we właściwym postępowaniu względem ludzi, ale też w odpowiednim udziale we mszy świętej. Jeżeli dzisiaj katecheci uczą katechezy, to w ramach jej powinni wskazywać na Chrystusa, który - jak powie autor Listu do Hebrajczyków - „nam w wierze przewodzi i ją wydoskonala” (Hbr 12, 2). Należy koncentrować się na Jego zbawczej ofierze i dziele odkupienia. A przecież to dzieło odkupienia jest uobecniane właśnie podczas Eucharystii. To podczas niej wierni otrzymują słowo Boże i doświadczają miłości Chrystusa. Dlatego, ucząc katechezy, można ukazywać liturgię jako swoistego rodzaju zajęcia praktyczne.

\section{Uwagi praktyczne}

Aby młodych ludzi poprzez katechezę skutecznie przybliżyć do mszy świętej, należy ukazywać im Eucharystię w sposób zachęcający. Jak to robić? W tym zachęcającym ukazywaniu liturgii poprzez nauczanie katechetyczne należy przede wszystkim zachować ogólne zasady. Jakie to są 
zasady? Podstawową zasadą jest, aby przede wszystkim słuchać mądrości Kościoła. Niestety istnieje w katechetach od czasu do czasu pokusa, aby zmieniać lub udoskonalać coś w liturgii na własną rękę. Uważają, że przemawiają za tym względy duszpasterskie lub katechetyczne. To jest pokusa, której pod żadnym pozorem nie można ulegać. Dlaczego? Ponieważ tego typu dodatki bardzo często nie są rozumne, a co za tym idzie - nie spełniają swojej funkcji, w niektórych zaś przypadkach mają nawet skutki destrukcyjne. Warto przy tej okazji przywołać konstytucję soborową o liturgii świętej, która stwierdza: „Prawo kierowania sprawami liturgii należy wyłącznie do władzy kościelnej. Przysługuje ono Stolicy Apostolskiej oraz, zgodnie z prawem, biskupowi. Na mocy władzy udzielonej przez prawo, kierowanie sprawami liturgii w ustalonych granicach należy także do różnych prawnie ustanowionych konferencji biskupów, właściwych danemu terytorium. Dlatego nikomu innemu, chociażby nawet był kapłanem, nie wolno na własną rękę niczego dodawać, ujmować lub zmieniać w liturgii” (konst. Sacrosanctum Concilium, $22 \$ 1-3)$. W podobnym duchu wypowiada się Kodeks prawa kanonicznego w kan. $838 \$ 1-4$.

Tytułem wyjaśnienia powyższych stwierdzeń można wskazać na negatywne sytuacje związane z przygotowywaniem uczniów do przyjęcia niektórych sakramentów. O tych negatywnych przejawach traktują niektóre dokumenty Kościoła ${ }^{7}$, nie brak również wypowiedzi wielu polskich biskupów zawartych w opublikowanych wskazaniach ${ }^{8}$.

W przypadku Pierwszej Komunii Świętej bardzo często podkreśla się nadzwyczajny charakter tego dnia. Akcentowanie faktu, że w dniu Pierwszej Komunii Świętej Pan Jezus przyjdzie po raz pierwszy w Eucharystii do uczniów jest poprawne i jak najbardziej wskazane. Warto podkreślać, że

${ }^{7}$ Niektóre problemy zostaną omówione w dalszej części pracy na podstawie niniejszej literatury: Wprowadzenie teologiczne i pastoralne, 11-12, [w:] Obrzędy bierzmowania dostosowane do zwyczajów diecezji polskich, Katowice 2008, s. 21-23; Wprowadzenie teologiczne i pastoralne, 3, [w:] Obrzędy pokuty dostosowane do zwyczajów diecezji polskich, Katowice 2002, s. 21; Jan Paweł II, list apost. Misericordia Dei, 2.

${ }^{8}$ Por. Wskazania Biskupa Tarnowskiego dotyczące uroczystości I Komunii św., „Currenda. Pismo Urzędowe Diecezji Tarnowskiej” 157 (2007) nr 2. 
będzie to dla nich po raz pierwszy pełny udział we mszy świętej. Ale już zbyt rozbudowana otoczka związana z okazałymi strojami, niekończącą się ilością wierszyków, licznymi modyfikacjami w strukturze mszy świętej czy prezentami i przyjęciami w domach rodzinnych przyczyniają się do tego, że następne Eucharystie, w których dzieci uczestniczą, nie są dla nich aż tak atrakcyjne i ważne. I to jest błędem, ponieważ dzień Pierwszej Komunii Świętej powinien otworzyć bramę do częstego przyjmowania Eucharystii, a nie ją zamknąć na długie lata. Gdyby cała otoczka, o której mowa, była obiektywnie dobra, wówczas mielibyśmy obecnie pełne kościoły ludzi młodych, a tymczasem obecność tych quasi-liturgicznych dodatków sprawiła, że dzieci ukształtowane w taki sposób wydają się być dla głębokiego przeżywania Eucharystii pokoleniem straconym.

Ponadto podczas przygotowania do Pierwszej Komunii Świętej w wielu przypadkach wychowuje się dzieci do rozumienia Eucharystii, która jest ucztą, pomijając jej zasadniczy rys, że jest ona przede wszystkim ofiarą (por. Jan Paweł II, enc. Ecclesia de Eucharistia, 10). Pierwowzorem ofiary eucharystycznej były przecież ofiary Starego Testamentu. Wówczas kult oddawany Bogu łączył w sobie zarówno ofiarę, jak i ucztę. Ze zwierząt składanych Panu część przeznaczano na ofiarę, część natomiast na następującą po złożonej ofierze ucztę (por. Kpł 7, 11-34). Dlatego mszę świętą należy rozumieć integralnie: jako ofiarę, która zawsze kończy się ucztą (por. Katechizm Kościoła katolickiego, 1382; Jan Paweł II, enc. Ecclesia de Eucharistia, 12). I do takiego przeżywania Eucharystii należy wychowywać również katechizowanych.

Zdarzają się też w wielu parafiach quasi-przygotowania polegające na uczeniu dzieci podchodzenia do komunii świętej. Tyle tylko, że to podchodzenie ćwiczy się podczas rzeczywistej mszy świętej, gdy inni uczestnicy liturgii przystępują do komunii świętej. Wówczas dzieci mają podchodzić razem $\mathrm{z}$ innymi wiernymi, z tą różnicą, że dzieci mają mieć palec na ustach i wtedy nie przyjmują Eucharystii, ale otrzymują błogosławieństwo. Nie jest to poprawne z kilku powodów. Po pierwsze jest problemem dla udzielającego sakrament, gdyż powinien z szacunkiem odnosić się do Eucharystii, on tymczasem wciera w czoła dzieci partykuły Eucharystii. Po drugie wszystkie dzieci błogosławić mogą osoby duchowne, swoje dzieci mogą błogosławić rodzice, zaś swoich uczniów katecheci. Co dzieje się 
w sytuacji, gdy te krzyżyki na czole wykonują nadzwyczajni szafarze komunii świętej? Po trzecie zaciera się istotę komunii świętej, która powinna być nie tyle spotkaniem towarzyskim w miłej atmosferze, co bardziej zjednoczeniem z ofiarą Chrystusa. I po czwarte modyfikuje się strukturę mszy świętej, gdyż moment błogosławieństwa wiernych przenosi się z końca liturgii do obrzędów komunii świętej. Niestety ten zwyczaj - znajdujący coraz większe grono zwolenników - nijak ma się do słów Jezusa: „Pozwólcie dzieciom przychodzić do Mnie, nie przeszkadzajcie im..." (Mk 10, 14), bo padają one z ust Chrystusa w innym kontekście niż mowa o Eucharystii. Takie praktyki nie mają zatem ani teologicznych, ani duszpasterskich racji. Utrudniają jedynie skuteczne prowadzenie odpowiedniej katechezy liturgicznej. A przecież - jak podkreślił Jan Paweł II w swojej ostatniej encyklice - „Eucharystia jest zbyt wielkim darem, ażeby można było tolerować dwuznaczności i umniejszenia” (Jan Paweł II, enc. Ecclesia de Eucharistia, 10).

Wiele do życzenia pozostawia też sama msza święta przeżywana w dzień Pierwszej Komunii Świętej. Wszystkim odpowiedzialnym za zorganizowanie w parafiach takiej uroczystości warto polecić wskazania ogłoszone między innymi w 2007 roku przez biskupa tarnowskiego. Podkreśla on, że msza święta w dniu Pierwszej Komunii Świętej - zresztą jak każda inna Msza święta - „powinna być celebrowana z zachowaniem wszystkich przepisów liturgicznych, a zatem:

- należy unikać liturgicznych lub quasi-liturgicznych «dodatków», które nie są niezbędne, a włączone w liturgię mogłyby przysłonić właściwy obrzęd;

- dzieci winny skupić się na pobożnym uczestnictwie w liturgii Mszy św., a nie na występach wobec zgromadzonej wspólnoty;

- należy unikać organizowania w czasie liturgii akademii z recytacją wierszyków, przemówień, śpiewem piosenek itp.;

- Słowo Boże winni czytać rodzice (oni są pierwszymi nauczycielami wiary swoich dzieci). Również psalm responsoryjny winni śpiewać rodzice. Dzieci nie są przygotowane do pełnienia funkcji lektora czy kantora;

- dzieci mogą odczytać wezwania modlitwy powszechnej, zwłaszcza za swoich rodziców, nauczycieli, katechetów. Rodzice zaś za swoje dzieci;

- dzieci winny przynieść w procesji do ołtarza dar chleba i wina oraz swoje zobowiązania powstrzymania się od palenia papierosów i picia alkoholu; 
- roztropnemu rozeznaniu przez Księdza Proboszcza pozostawia się wybór praktyki przyjmowania przez dzieci I Komunii św. w towarzystwie rodziców, czy też bez nich;

- należy odejść od zwyczaju, o ile taki istnieje, przygotowania się w czasie modlitwy eucharystycznej z książeczek do przyjęcia Komunii św. Najlepszym przygotowaniem jest czynny udział w liturgii Mszy św. Przygotowanie z książeczki może być przed Komunią poza Mszą św.;

- dziękczynieniem po Komunii św. powinno być wspólne uwielbienie, adorowanie Jezusa Eucharystycznego. Może nim być wspólna modlitwa, właściwa pieśń, a nie czytanie przez dzieci modlitw z książeczki;

- wszelkiego rodzaju przemówienia, podziękowania powinny być krótkie i zwięzłe. Należy je wygłaszać po zakończeniu Mszy św."9.

Kolejną kwestią jest właściwe przygotowanie uczniów do przyjęcia sakramentu bierzmowania. Niewątpliwie jest to trudne katechetycznie zadanie. Nie bez znaczenia jest tutaj również wiek potencjalnych kandydatów, który poeta Adam Mickiewicz - zresztą zgodnie z prawdą - z jednej strony określa jako wiek górny - pełny ideałów i wzniosłych intencji, ale $\mathrm{z}$ drugiej strony zaś jako wiek durny - w którym nie brakuje błędów i porażek ${ }^{10}$.

Na co należy zwrócić uwagę w ramach przygotowania uczniów do bierzmowania? O istocie tego przygotowania przypomina jeden $\mathrm{z}$ najnowszych dokumentów partykularnych: Instrukcja katechetyczno-pastoralna o przygotowaniu młodzieży do sakramentu bierzmowania $w$ diecezji legnickiej. Znaleźć tam można wskazania, że „sakrament bierzmowania nie może ograniczać się do samej celebracji. W przeciwnym razie jego przyjęcie prowadzić będzie do zwykłego rytualizmu lub formalizmu, co w konsekwencji osłabi jego znaczenie dla życia chrześcijanina. Zgodnie z założeniami Soboru Watykańskiego II przyjęcie sakramentu bierzmowania powinno poprzedzać odpowiednie przygotowanie. Jest ono konieczne dla osiągnięcia owocnych skutków sakramentu (por. KDK 11; KKK 1289).3. Przygotowanie do sakramentu bierzmowania powinno mieć

\section{Tamże.}

${ }^{10}$ Por. A. Mickiewicz, Polały się łzy..., [w:] tenże, Liryki lozańskie, s. 4, http://wolnelektury.pl/media/book/pdf/liryki-lozanskie_16.pdf (30 IX 2013). 
na celu doprowadzenie kandydata do spotkania z Chrystusem, a nawet do głębokiej z Nim zażyłości (por. CT 7), a także do otwarcia się na działanie Ducha Świętego, by mógł on lepiej podjąć apostolską odpowiedzialność życia chrześcijańskiego oraz odważnie wyznawać swoją wiarę (por. KKK 1285). Powinno także obudzić zmysł przynależności do Kościoła powszechnego i wspólnoty parafialnej. Czas przygotowania należy tak zorganizować, by kandydaci mieli szczególną okazję do bliższego przyjrzenia się parafialnej wspólnocie i włączenia się w jej życie. Parafialna wspólnota natomiast winna nieustannie wspierać swoją modlitwą osoby przygotowujące się do przyjęcia tego sakramentu" ${ }^{11}$. Ponadto z pewnością należy zadbać - co z kolei podkreśla Wprowadzenie teologiczne i pastoralne do księgi Obrzędy bierzmowania - o spełnienie warunków, które zapewnią owocne przyjęcie tego sakramentu. Oznacza to, że trzeba postawić wymagania i być konsekwentnym, ale też nie uzależniać wszystkiego od dojrzałości kandydata. Należy przecież pozostawić też przestrzeń do działania łasce Bożej. W przygotowaniu do bierzmowania bardzo często zapomina się o tym jakże istotnym elemencie. Katecheci koncentrują się na coraz to bardziej wymyślnych formach egzaminu do bierzmowania i kategorycznie wymagają spełnienia wszystkich zobowiązań. Taka postawa może przynieść więcej szkody niż dobrego. Dlatego należy postawić pewne wymagania, ale też dać szansę łasce Bożej, w którą po przyjęciu bierzmowania dana osoba zostanie wyposażona. To nie oznacza naturalnie, że nie może być sytuacji odłożenia przyjęcia tego sakramentu w czasie. Nie tylko można, ale nawet trzeba to uczynić, gdyby istniało niebezpieczeństwo, że ten sakrament nie będzie owocnie przyjęty, to znaczy nie pociągnie za sobą posłuszeństwa Chrystusowi i dawania zdecydowanego świadectwa lub też zostanie przyjęty na sposób świętokradzki ${ }^{12}$.

Ostatnim problemem, który wymaga omówienia, jest odpowiednia formacja katechizowanych do właściwego korzystania z sakramentu pojednania i pokuty. Zbyt rzadko w nauczaniu katechetycznym wskazuje

${ }^{11} \mathrm{http}: / /$ www.diecezja.legnica.pl/files/pdf/Instrukacja_do_bierzmowania.pdf (30 IX 2013).

${ }^{12}$ Wprowadzenie teologiczne i pastoralne, 11-12, [w:] Obrzędy bierzmowania dostosowane do zwyczajów diecezji polskich, Katowice 2008, s. 21-23. 
się na właściwy powód przystępowania do tego sakramentu. Nie chodzi tu przecież jedynie o spełnienie obowiązku wynikającego z przykazania kościelnego. Nie można też wszystkiego tłumaczyć lękiem przed potępieniem. Gdy mówi się o pięciu warunkach sakramentu pokuty, dotyka się zagadnienia żalu za grzechy. Bardzo często w nauczaniu katecheci skupiają się nad żalem niedoskonałym. Tymczasem w katechizowanych przystępujących do spowiedzi świętej należy rozbudzić pragnienie żalu doskonałego. Żal niedoskonały towarzyszy penitentowi wtedy, gdy przystępuje do tego sakramentu z powodu lęku przez sprawiedliwością Boga. Powinien natomiast raczej przystąpić do spowiedzi świętej kierowany żalem doskonałym, to znaczy żalem wynikającym z miłości do Boga (por. Katechizm Kościoła katolickiego, 1452-1453).

Także w tym zagadnieniu ważny jest czas przystępowania do sakramentu pojednania i pokuty. Ciągle katecheci formują uczniów - zresztą bardzo często nieświadomie - do spowiadania się podczas mszy świętej. A to jest błąd, który utrudnia właściwe wychowanie ich do dojrzałego uczestnictwa w Eucharystii. Instrukcja Eucharisticum mysterium z 1967 roku - a więc już jakiś czas temu napisana i ciągle aktualna - mówi, że „wytrwale należy przyzwyczajać wiernych, aby przystępowali do sakramentu pokuty poza Mszą św., zwłaszcza w określonych godzinach, tak aby jego udzielanie dokonywało się w spokoju i z prawdziwą ich korzyścią, jak również nie przeszkadzało im w czynnym uczestnictwie we Mszy świętej” (nr 35). Wprawdzie nie ma zakazu spowiadania podczas mszy świętej, ale zarówno Wprowadzenie teologiczne i pastoralne zawarte w księdze Obrzędy pokuty, na podstawie którego przygotowuje się uczniów do przystępowania do spowiedzi świętej, jak również nowszy dokument - list apostolski Misericordia Dei zgodnie podkreślają, że wiernych należy przyzwyczajać, aby spowiadali się poza mszą świętą ${ }^{13}$.

${ }^{13}$ Wprowadzenie teologiczne i pastoralne, 3, [w:] Obrzędy pokuty dostosowane do zwyczajów diecezji polskich, Katowice 2002, s. 21; Jan Paweł II, list apost. Misericordia Dei, 2. 


\section{Konieczność formacji katechetów}

Na koniec krótko należy zwrócić uwagę na konieczność stałej formacji katechetów. To zagadnienie łączy się z właściwym postrzeganiem liturgii w katechezie. Katecheci uczestniczą w misji Chrystusa. Są zatem przekazicielami Jego nauki. Aby powierzone im z mandatu Kościoła zadanie wypełniali należycie, nie tylko powinni dbać o odpowiednie metody w nauczaniu, ale znacznie bardziej muszą odznaczać się odpowiednimi cechami. Dyrektorium ogólne o katechizacji podkreśla: „Najszlachetniejsze bowiem przymioty ludzkie i chrześcijańskie katechety bardziej gwarantują owocność katechezy aniżeli wyszukane metody" (nr 71).

Być katechetą oznacza realizować specyficzne powołanie. „Tak jak apostołowie wezwani przez Chrystusa poszli za swoim Mistrzem, katecheta winien głoszenie Ewangelii przyjąć wraz z odpowiedzią wiary na wezwanie Chrystusa i realizację Jego posłannictwa"14. Dlatego katecheci powinni starać się zdobywać odpowiednie cnoty charakteru oraz nieustannie troszczyć się o własną formację. W kontaktach z młodzieżą powinni być świadkami, co niewątpliwie będzie skutkiem prowadzenia przez nich pogłębionego życia sakramentalnego, pielęgnowania właściwych relacji międzyludzkich, a także troski o wygląd zewnętrzny. Jeśli katecheci mają prowadzić katechizowanych do komunii z Jezusem Chrystusem, to sami powinni trwać w głębokiej zażyłości „z Chrystusem i z Ojcem w Duchu Świętym" (Dyrektorium ogólne o katechizacji, 235) ${ }^{15}$. Każdy katecheta musi być niewysychającym źródłem wiary, które da pić zagubionym w życiu uczniom. Źródłem staje się dzięki modlitwie, intensywnemu życiu sakramentalnemu, głębokiej wierze w to, że oddanie swego życia Jezusowi opłaca się ${ }^{16}$. Wówczas zapewne nie będzie miał też problemów z prowadzeniem uczniów poprzez katechezę do właściwego przeżywania liturgii.

${ }^{14}$ A. Offmański, Katecheta permanentnie kształtujący się, [w:] Dzisiejszy katecheta - stan aktualny i wyzwania, Kraków 2002, s. 171.

${ }^{15}$ Konferencja Episkopatu Polski, Dyrektorium Katechetyczne Kościoła katolickiego w Polsce, Kraków 2001, 150.

${ }^{16}$ A. Błoniak, Być świadkiem, „Katecheta” 1998 z. 2, s. 56. 


\section{Zakończenie}

Poruszając zagadnienie relacji pomiędzy katechezą a liturgią spontanicznie dochodzi się do wniosku, że nie są to jedynie związki teoretyczne. Ma się tutaj bowiem do czynienia z czymś niezwykle aktywnym. Prawdą jest, że liturgia domaga się katechezy, a katecheza domaga się liturgii. Właściwa posługa katechetyczna podejmowana w ramach zajęć szkolnych i pogłębiona poprzez katechezę parafialną związaną z przygotowywaniem do przyjęcia sakramentów sprawia, że uczniowie mogą zbliżyć się do liturgii. Nie jest ona jedynie kultem składanym Bogu przez wierzących, ale ukazuje prawdziwe i aktywne działanie Boga pośród ludzi. Dzięki takiemu doświadczeniu liturgii katechizowani lepiej rozumieją tajemnice wiary i potrafią nimi żyć na co dzień.

\section{Abstrakt}

Ciągle aktualne jest poszukiwanie odpowiedzi na pytanie: Jak uczyć uczniów religii, aby doprowadzić ich do odpowiedniego udziału w liturgii? Aby wypełnić to zadanie, należy katechizowanych nakarmić słowem Bożym i łaską Boga. Przestrzenią głoszenia słowa Bożego i obdarzania łaską Boga jest zarówno katecheza, jak i liturgia - każda z nich, we właściwym sobie zakresie. Pomiędzy liturgią a katechezą zachodzą wzajemne relacje. Liturgia domaga się katechezy, a katecheza domaga się liturgii. Aby młodych ludzi poprzez katechezę skutecznie przybliżyć do Mszy świętej, należy ukazywać im Eucharystię w sposób zachęcający. W realizacji tego zadania należy kierować się mądrością Kościoła: „Prawo kierowania sprawami liturgii należy wyłącznie do władzy kościelnej [...] Dlatego nikomu innemu, chociażby nawet był kapłanem, nie wolno na własną rękę niczego dodawać, ujmować lub zmieniać w liturgii” (konst. Sacrosanctum Concilium, 22, \$1-3). Te wskazania mają swoje zastosowanie zwłaszcza w przygotowaniu katechizowanych do sakramentów: pierwszej Komunii świętej, bierzmowania i spowiedzi świętej. Jednak, aby został w pełni osiągnięty cel doprowadzenia katechizowanych do dojrzałego udziału w liturgii, należy zadbać także o formację katechetów. Oni jako przekaziciele nauki Chrystusa, powinni odznaczać się odpowiednimi cechami. „Najszlachetniejsze bowiem 
przymioty ludzkie i chrześcijańskie katechety bardziej gwarantują owocność katechezy aniżeli wyszukane metody" (Dyrektorium ogólne o katechizacji, 71).

\section{Słowa kluczowe}

Liturgia, katecheza, przygotowanie, sakramenty

\section{Abstract}

\section{Liturgy in catechesis}

The search for the answer of the following question is still actual: How to teach pupils religion in order to bring them to the proper participation in liturgy? To fulfil this assignment means to feed the catechised with the word and grace of God. Both the liturgy and catechesis are in their own ways a space for preaching the word of God and experiencing the grace of God. There are close correlations between liturgy and catechesis. Liturgy needs catechesis and catechesis needs liturgy. The Eucharist should be presented in catechesis in an encouraging way to bring the young people to the Holy Mass. Carrying out this assignment should be based on the wisdom of the Church: "Regulation of the sacred liturgy depends solely on the authority of the Church [...] Therefore no other person, even if he be a priest, may add, remove, or change anything in the liturgy on his own authority" (Sacrosanctum Concilium, 22, 1-3). Those recommendations are also applicable in preparing the catechised to the sacraments in particular: First Communion, confirmation and confession. However, if the assignment of bringing the catechised to a mature participation in the liturgy is to be fully achieved the catechists should be taken in care as well. They transfer the teaching of Christ and should have proper traits. "For the noblest human and Christian attributes guarantee more fruitful catechesis than any elaborated methods" (Dyrektorium ogólne o katechizacji, 71).

\section{Keywords}

Liturgy, catechesis, preparation, sacraments 